\title{
VIEWPOINTS
}

\section{The Absence of Islam in the 'Arab Spring'}

\author{
Mohammad Hashim Kamali*
}

While most of the recent movements in the Muslim world have been spearheaded by Islamic parties and leaders, the Arab uprising is surprisingly led by civil society, especially the youth. The Arab uprising is still unfolding and uncertainties exist that may yet be clarified in the course of time. However, one question that arises is over the relative absence of Islam in what has been seen so far.

Islam has been closely aligned with most of the reform movements in the Arab world during the independence and post-independence periods. Two other themes that have also emerged, with varying degrees of consistency, are Arab nationalism (al-qawmiyyah al-'arabiyyah) and - for a brief period in the era of Egypt's Gamal Abdel Nasser - socialism.

Some of the remnants of Baath partisan movements that remained in Syria and Iraq were also aligned with socialism. Yet, Islam and its various interpretations have imbued much of the 20th century's revivalist movements in the Arab world. More recently, Iraq under Western occupation saw a fresh wave of Islamic revivalism as an identity marker of sorts. Afghanistan has similarly seen a new tide of Islamic resurgence of the Taliban variety, return of tribalism and emergence of warlords and drug barons.

Whereas most of the Islamic movements of recent decades in the Muslim world were spearheaded by Islamic parties and leaders, the Arab uprising is led by civil society, especially the youth, and it is more widely spread across all strata of the population, including non-Muslims (Coptic Christians in Egypt, for example), in the demand for accountability and good governance.

On a broader note, the closing decades of the twentieth century brought identity awareness to the forefront of popular consciousness, manifesting a reaction to strident globalisation, which had begun to impinge on local identities and cultures. Religions, ethnicities and cultures became more assertive of their own characteristics.

Even if one remained circumspect of Samuel Huntington's 'clash of civilisations' theory, the present century has often been associated with clashes of identities and cultures. The Islamic identity of the Arab world is, somehow, not in the limelight. It

* Mohammad Hashim Kamali is the Founding Chairman and CEO of IAIS Malaysia. This Viewpoint appeared first on 4 June 2011 in the New Straits Times (Kuala Lumpur). 
may well be that Arabism rather than Islam strikes a closer note of association with the current uprising.

The faces of change seen now could be explained by reference to certain factors, among which are the persistent gaps between the theoretical articulations of Islamic ideologues and the grasping misconduct of the long-serving dictators.

Islamic parties and movements delivered their message that Islam stood for judicious, accountable and consultative governance even if it did not subscribe to a particular model. They failed, nevertheless, to make an impact on practical politics; the long-serving dictators resisted both the propagators of Western democracy and their Islamic counterparts. The dictators are clearly the major cause of popular discontent.

The Islamic ideologues were also slow to adjust their preoccupation with dogmatic and prescriptive assertions. Only in the late 1990s were they noted to have turned to the ballot box in significant numbers, and only then did they start to take more service-oriented postures by helping the people when practical help was needed, such as in times of natural calamity.

To be sure, accountability and good governance were advocated in the Islamic revivalist discourse and Arab thought, as evidenced by the significant body of literature produced on the principles of governance, which fell short, however, of providing a viable alternative to the then prevailing status quo of political repression and abuse.

Hypocrisy, incredulity and lip service also marked electoral and constitutional politics. Elections were held, new charters and constitutions spoke of commitment to basic rights and democratic rule, but lost credibility in the face of persistent violation and abuse by the reigning police state. Past experience thus failed to set a valid precedent or a model for the future, resulting in what is now seen: loss of public confidence in both the dictators and Islamic parties.

A question that arises now is what happens next, when the dust of the uprising settles. The quest and concern for authenticity remain and apprehensions persist that past errors should not be repeated.

During the post-colonial period, the Muslim world heard clarion calls and promises from the outgoing colonialists to bring in democracy and constitutionalism. Westerneducated elites in these countries remained receptive to Europe's inculcations with the result that the Muslim world was left with a legacy of constitutions, judicial and education systems that were modeled on their European prototypes.

After decades of democracy euphoria, the Muslim world, and the Arab Middle East in particular, instead of democracy and constitutional rule, saw a series of destructive military coups. A certain disillusionment with Western double-standards also sank in.

The West's preaching of democracy and constitutional government was matched by its support of 'friendly' corrupt dictators. The quest for authenticity grew with its 
consequent demand that law and government in the Muslim lands must bear harmony with their own heritage.

Muslim commentators also became more vociferous in their critique of the Western democracy model, which they saw as a misfit for the Muslim milieu. For Western political democracy is grounded in post-Enlightenment secularism and its expressed aversion to divine revelation, religious and metaphysical truth. Whereas in Islam, as in other major religions, ethical norms of right and wrong are determined by reference to divine revelation, the secularist nation-state of eighteenth-century Europe subscribed to the supremacy of reason and scientific truth.

Now that democracy is again at the centre stage of public discourse in the Arab world, one wonders whether the latter has an intellectual template and vision of its own future or whether it is likely to relapse to a pattern of renewed borrowing from Western sources and their hallowed ideas of democracy and good governance.

A moderate Islamic model, such as the one advocated by the Nahdah movement in Tunisia, which seeks to combine consultative governance with electoral democracy and separation of powers, may appeal to the Arab masses. Turkey and Malaysia, which take economic development as a priority agenda of their participatory systems of rule, may also prove to be influential. 